\title{
Analyses and localization of pectin-like carbohydrates in cell wall and mucilage of the green alga Netrium digitus
}

\author{
Magdalena Eder • Ursula Lütz-Meindl
}

Received: 22 January 2009/Accepted: 9 March 2009 / Published online: 2 April 2009

(C) The Author(s) 2009. This article is published with open access at Springerlink.com

\begin{abstract}
The unicellular, simply shaped desmid Netrium digitus inhabiting acid bog ponds grows in two phases. Prior to division, the cell elongates at its central zone, whereas in a second phase, polar tip growth occurs. Electron microscopy demonstrates that Netrium is surrounded by a morphologically homogeneous cell wall, which lacks pores. Immunocytochemical and biochemical analyses give insight into physical wall properties and, thus, into adaptation to the extreme environment. The monoclonal antibodies JIM5 and JIM7 directed against pectic epitopes with different degrees of esterification label preferentially growing wall zones in Netrium. In contrast, 2F4 marks the cell wall only after experimental de-esterification. Electron energy loss spectroscopy reveals Ca-binding capacities of pectins and gives indirect evidence for the degree of their esterification. An antibody raised against Netrium mucilage is not only specific to mucilage but also recognizes wall components in transmission electron microscopy and dot blots. These results indicate a smooth transition between mucilage and the cell wall in Netrium.
\end{abstract}

Dedicated to Professor Cornelius Lütz on the occasion of his 65 th birthday

M. Eder • U. Lütz-Meindl $(\square)$

Cell Biology Department, Plant Physiology Division,

University of Salzburg,

Hellbrunnerstraße 34,

Salzburg A-5020, Austria

e-mail: ursula.meindl@sbg.ac.at

Present Address:

M. Eder

Leibniz Institute for New Materials,

Campus D2-2,

Saarbrücken D-66123, Germany

e-mail: magdalena-eder@gmx.at
Keyword Alga $\cdot$ Cell wall $\cdot$ Confocal laser scanning microscopy $\cdot$ Mucilage $\cdot$ Pectins $\cdot$ TEM

\section{Introduction}

Conjugating green algae (Zygnemophyceae, Streptophyta), which preferentially colonize acid bog areas, have inspired scientists for a long time because of their ornamented morphology, their huge shape diversity, and their complex cell symmetry. Based on their plastid morphology (Brook 1981; West and West 1904) and on molecular phylogenetic data (Gontcharov et al. 2003, 2004), Zygnemophyceae have been subdivided into Zygnematales and Desmidiales. Netrium digitus (Ehrenb.), belonging to the family Mesotaeniaceae and, thus, to the Zygnematales, has often been considered as an intermediate organism between saccoderm (Mesotaeniaceae) and placoderm desmids (Desmidiales, Brook 1981; Gontcharov et al. 2003; Yamagishi 1963).

The diversity in structure and cell wall morphology within the Zygnemophyceae has been used as key for taxonomy in earlier studies (Brook 1981; Mix 1972, 1975). Composition and architecture of the cell wall also give insights into the adaptation of the algae to their environment. Netrium (Mesotaeniaceae) possesses a single-layered, homogeneous "smooth" cell wall, which lacks pores (Mix 1972). In contrast, cell walls of Desmidiaceae usually consist of two pieces. During their development, the growing half cell is surrounded by a thin, flexible primary wall containing randomly distributed cellulose fibrils. After growth is completed, the primary wall is underlaid by a stiffer and thicker secondary wall with orientated cellulose fibrils and integrated pores, warts, and spines (Mix 1975). The secondary wall finally replaces the primary wall, which is shed by a sudden onset of mucilage excretion (Brook 
1981, Kiermayer 1964; Mix 1975). In some evolutionary key species like Penium margaritaceum (Peniaceae), Closterium acerosum (Closteriaceae), and Micrasterias denticulata (Desmidiaceae), the cell wall has been characterized by immunological and biochemical methods (Baylson et al. 2001; Domozych et al. 2006; Kim et al. 1991; Lütz-Meindl and Brosch-Salomon 2000; Nakashima et al. 2006). The existence of cellulose synthase complexes in the plasma membrane was described for the first time in desmids (Giddings et al. 1980; Kiermayer and Sleytr 1979). Additionally, cellulose fibrils were characterized in Micrasterias (Hanley et al. 1997; Kim et al. 1991), and particularly pectin-like components (Baylson et al. 2001; Domozych et al. 2006; Eder and Lütz-Meindl 2008; Lütz-Meindl and Brosch-Salomon 2000); and also hemicelluloses (Eder et al. 2008) were localized by using monoclonal antibodies raised against cell wall components of higher plants.

Biochemical analyses of Closterium and Penium cell walls revealed both common monosaccharides and the structural configuration of homogalacturonan (Baylson et al. 2001; Domozych et al. 2006). The latter is one of the most common pectins in higher plants and consists of a linear chain of ( 1 to $>4)-\alpha$-D-galacturonic acid (Carpita and Gibeaut 1993). The carboxyl groups of homogalacturonan consist of methyl-esterified and non-esterified conformations. Non-esterified chains are able to form intermolecular associations through calcium bridging, thus, creating a stiffened pectate gel (Goldberg et al. 1996). In contrast, highly methyl-esterified pectins facilitate growth because of their loose structure. In this study, pectic components and their degree of methyl esterification were investigated in Netrium to determine growing and nongrowing zones of the morphological homogeneous cell wall to discover variations in pectin-conformation during development and to obtain insight into cell wall composition of this "basic" desmid in comparison to other algae and higher plants.

Acidic polysaccharides like pectins do not only occur in plant cell walls but also in mucilage. Most Zygnemophyceae are able to produce mucilage in huge quantities (Brook 1981; Chardard 1977; Domozych and Rogers-Domozych 1993; Kattner et al. 1977; Neuscheler 1967; Oertel et al. 2004; Rogers-Domozych et al. 1993; West and West 1904). Active mucilage excretion from one pole leads to gliding movements (Boney 1981; Lind et al. 1997; Oertel et al. 2004; Pickett-Heaps et al. 2001; Url and Kusel-Fetzmann 1973), which depend on nutrition and light conditions (Häder 1981, 1982; Häder and Wenderoth 1977; Neuscheler 1967; Trojánková and Poibyl 2006) and enable the cells to escape from unfavorable environmental conditions. Mucilage excretion over the whole surface facilitates the attachment of desmids to solid objects or to other algae, thus, building cell colonies and aggregates (Baylson et al. 2001; RogersDomozych et al. 1993; Surek and Sengbush 1981). Furthermore, mucilage protects algae during cell division and conjugation (Brook 1981; Oertel et al. 2004; PickettHeaps 1975), shields the cells against irradiation and drought (Boney 1981; Lütz et al. 1997; West and West 1904) and functions as substratum for interacting microorganisms (Kearns and Hunter 2000; Vammen 1977). Mucilage of at least some desmids consists of acidic polysaccharides (Brosch-Salomon et al. 1998; Menge 1976; RogersDomozych et al. 1993) and is partially recognized by antibodies against pectins of higher plants such as JIM5 and JIM7 (Eder and Lütz-Meindl 2008; Lütz-Meindl and Brosch-Salomon 2000).

Formation of different cell-wall layers and mucilage requires a highly specified production and secretion machinery with fast excretion mechanisms. Both cell-wall matrix material and mucilage are synthesized at the Golgi apparatus simultaneously and are transported to the cell periphery in different vesicle populations as observed in numerous transmission electron microscopic (TEM) studies (Kiermayer 1964; Meindl 1993; Oertel et al. 2004; RogersDomozych et al. 1993). Whereas cell wall containing vesicles fuse with particular areas of the plasma membrane (Meindl et al. 1992), mucilage can be excreted either through the cell wall or the pores (Domozych et al. 2006; Oertel et al. 2004; Rogers-Domozych et al. 1993).

In addition to cell-wall analyses, we created and partially characterized a polyclonal antibody against Netrium mucilage to follow the secretion pathway of mucilage vesicles. The antibodies JIM5, JIM7, and 2F4 raised against pectins of higher plants were applied to discriminate between mucilage and cell-wall components within vesicles and to identify pectin rich regions within the cell wall. In order to understand cell-wall properties in relation to growth, calcium-binding capacities of different cell wall and mucilage components were measured by electron energy loss spectroscopy (EELS) in TEM. In this way, we could determine the degree of pectin methyl esterification and obtain information on rigidity and stiffness of pectins in cell wall, mucilage, and the respective vesicles. The results on cell wall and mucilage composition in Netrium are compared to earlier results reported from closely related algae and higher plants.

\section{Material and methods}

\section{Materials}

All chemicals were purchased from Sigma-Aldrich (Vienna, Austria), unless stated differently. All antibodies were purchased from Plant Probes (Leeds, UK). 
Cultivation and digital time lapse photography

$N$. digitus was cultivated both in liquid desmid nutrient solution (adjusted to pH 3.8, Schlösser 1982) and on agar plates with varying agar concentration from $0.25 \%$ to $1.25 \%$. Cultures were kept under a constant temperature of $20^{\circ} \mathrm{C}$ and at a photoperiod of $14 \mathrm{~h}$ light and $10 \mathrm{~h}$ dark using Philips D26W/-1/19 tubes. Cells were subcultured every 4 weeks. The moving behavior of Netrium was analyzed using a CCD/RGB color video camera (Sony, Tokyo, Japan) connected to a binocular (Wild M3Z, Heerbrugg, Switzerland) and processed by a PicEd Cora software (Jomesa, Munich, Germany) using a Matrix PC Image SC frame grabber card (Matrix Vision, Oppenweiler, Germany) according to Holzinger and Lütz-Meindl (2003) and to Oertel et al. (2004).

\section{Labeling of the nucleus with Syto 16}

To determine the position of the nucleus, Netrium cells were collected and incubated in 1 to $5 \mu \mathrm{M}$ Syto 16 (Invitrogen, Lofer, Austria) for $1 \mathrm{~h}$ according to Holzinger and Lütz-Meindl (2003). Cells were washed in $\mathrm{H}_{2} \mathrm{O}_{\mathrm{dd}}$ and observed in a fluorescence microscope (Leitz Dialux, Wetzlar, Germany). Pictures were captured in an analogous system camera (Leitz Dialux 20, Wetzlar, Germany) on a 400 ASA black/white film and developed on AGFA photo paper (gradation 2, Vienna, Austria).

\section{Scanning electron microscopy}

Netrium cells were collected, fixed in 5\% glutaraldehyde dissolved in $50 \mathrm{mM}$ cacodylate buffer $(1 \mathrm{~h})$, washed in cycodylate buffer, post-fixed in $5 \% \mathrm{OsO}_{4}(1 \mathrm{~h})$, dehydrated in increasing concentrations of ethanol, and critical point dried in a Bal-Tec CPD 030 (Balzers, Liechtenstein). In some experiments, cells were either treated with Bisolvon containing bromhexin $(90 \mathrm{~min}$, Boehringer Ingelheim, Zürich, Schweiz) or with $0.1 \mathrm{~N} \mathrm{HCl}$ (15-40 min) and ultrasonicated for $30 \mathrm{~s}$ to $2 \mathrm{~min}$ between glutaraldehyde and $\mathrm{OsO}_{4}$ fixation to remove mucilage envelopes. Dried cells were gold sputtered (ca. $10 \mathrm{~nm}$ ) and viewed in an environmental scanning electron microscope ESEM XL 30 (Philips FEI, Eindhoven, The Netherlands) operated at 20 to $25 \mathrm{kV}$ (Vitkov et al. 2001).

Separation of Netrium cells and mucilage and biochemical monosaccharide analyses

Algae were concentrated, centrifuged, and separated from mucilage as described previously (Rogers-Domozych et al. 1993; Oertel et al. 2004). After centrifugation, Netrium cells remained as pellet, whereas mucilage was situated as interface between cells and nutrient medium. Cells and mucilage were collected separately, and Netrium cells were washed tree times to remove remaining mucilage. Both samples were freeze-dried. For cell-wall extraction, freeze-dried algae were ground to a fine powder in liquid nitrogen; cell wall was precipitated in $80 \%$ ethanol; the remaining pellet was treated with DMSO for $24 \mathrm{~h}$ to remove starch, washed in methanol/chloroform $(1: 1, v / v)$ and acetone, and finally, dried at room temperature as described in Ray and Lahaye (1995). Monosaccharides were analyzed by gas chromatography according to Eder et al. (2008). In brief, cell wall and mucilage were hydrolyzed either in $2 \mathrm{M}$ trifluor acetic acid (TFA) for $2 \mathrm{~h}$ at $110^{\circ} \mathrm{C}$ or in $13 \mathrm{M} \mathrm{H}_{2} \mathrm{SO}_{4}$ for $1 \mathrm{~h}$ at RT and $2 \mathrm{~h}$ at $110^{\circ} \mathrm{C}$ (for the cellulose-rich fraction) and methanolized in dry methanol/HCl $\left(1 \mathrm{M}, 16 \mathrm{~h}, 80^{\circ} \mathrm{C}\right)$. Alditol acetate derivates were prepared and analyzed by gas chromatography with conditions according to Ray et al. (2004). The resulting data were analyzed with Star Chromatography Work Station software.

\section{Antibody production and dot blotting experiments}

Mucilage extracted from Netrium cultures was resuspended in sterile phosphate-buffered saline (PBS; 1:2), homogenized with equal amounts of complete Freund's adjuvant, and injected into female $\mathrm{BALB} / \mathrm{c}$ mice, obtained from the animal breeding facilities Charles River (Sulzfeld, Germany). The booster immunization was administered 2 weeks later using incomplete Freund's adjuvant (Serva, Germany). Sera were taken 2 weeks later and analyzed for specific binding on dot blotting experiments.

For blotting experiments, $3 \mu \mathrm{l}$ of mucilage from Netrium and extracted cell wall were spotted onto nitrocellulose membranes (Sartorius, Göttingen, Germany). Mucilage was diluted 1:1 with fixative reagent containing $1 \% \mathrm{OsO}_{4}$ and $0.05 \%$ uranyl acetate for TEM as control to show that the fixatives do not influence the immunoreaction. For antibody characterization, each 2 and $20 \mathrm{mg} / \mathrm{ml}$ of commercial AGPs from gum arabic, xyloglucan from tamarind, $\beta$-glucan from barley, and pectin from citrus were applied to the membrane. The membrane was blocked with 5\% defatted dry milk dissolved in trisma-buffered saline (TBS; $150 \mathrm{mM} \mathrm{NaCl}$, $\mathrm{pH}$ 7.5) for $1 \mathrm{~h}$ at RT, rinsed and incubated in the antimucilage antibody (1:600) for $2 \mathrm{~h}$ at RT. Blots were washed and incubated in the secondary antibody (antimouse horseradish peroxidase conjugated, diluted 1:4,000) for $2 \mathrm{~h}$ at RT. The membranes were washed again and antibodies bound to the membrane were detected by an ECL-reagent (Amersham, Vienna, Austria) on an X-ray film. 
Antibody labeling in CLSM and TEM

A set of antibodies raised against cell-wall epitopes in higher plants were applied to Netrium. JIM5 (up to $40 \%$ methyl-esterified homogalacturonan, Knox et al. 1990; Willats et al. 2000), JIM7 (15\% to $80 \%$ homogalacturonan, Knox et al. 1990; Willats et al. 2000), 2F4 (known to recognize non-esterified homogalacturonan cross linked by calcium, Liners et al. 1989), and a polyclonal antibody against mucilage of Netrium were applied. Secondary antibodies were used corresponding to the references given above.

Immunofluorescence labeling was modified according to Eder and Lütz-Meindl (2008). In brief, different developing stages of Netrium cells were chemically fixed in $50 \mathrm{mM}$ 1,4-piperazinediethanesulfonic acid buffer $(\mathrm{pH}$ 7.4) with $4 \%(v / v)$ paraformaldehyde and $1 \mathrm{mM} \mathrm{CaCl}_{2}$ for $1 \mathrm{~h}$. In some cases, cells were chemically de-esterified with $0.05 \mathrm{M}$ $\mathrm{NaOH}(\mathrm{pH}$ 12.4) and washed three times in PBS before immunocytochemical treatments. For antibody labeling, cells were blocked in PBS containing 0.1\% Tween and $2 \%$ BSA for $30 \mathrm{~min}$, washed three times and incubated in the first antibodies JIM5, JIM7, and 2F4 (each diluted 1:10 in $0.1 \%$ Tween) and an antibody against mucilage (diluted 1:200) for $2 \mathrm{~h}$ at RT. Cells were washed and incubated in the corresponding secondary antibody (each diluted 1:50) for $2 \mathrm{~h}$ at RT. After four final washing steps, cells were transferred to glass slides, sealed with vaseline, and viewed in a Zeiss Axiovert $100 \mathrm{M}$ equipped with a confocal laser scanner (Zeiss LSM 510, Oberkochen, Germany). Samples were excited at $488 \mathrm{~nm}$ (argon laser) and examined using a $505-550 \mathrm{~nm}$ band pass filter. Images were analyzed with Zeiss LSM 510 software.

Immunogold labeling for TEM was performed according to Eder and Lütz-Meindl (2008) and to Oertel et al. (2004). In short, grids with ultrathin sections were blocked for $40 \mathrm{~min}$ in TBS containing $0.05 \%$ Tween 20 and $2 \%$ bovine serum albumin, followed by incubation into the primary antibody at $4^{\circ} \mathrm{C}$ for $16 \mathrm{~h}$ (JIM5 and JIM7, diluted 1:20, anti-mucilage, diluted 1:200 and 2F4, diluted 1:10). After four washing steps, grids were incubated in the corresponding secondary antibody, which was $10 \mathrm{~nm}$ gold conjugated and diluted 1:60 with TBST for $1 \mathrm{~h}$ at room temperature. Grids were finally rinsed twice in TBST and twice in water, dried, and viewed in a TEM.

\section{TEM, EELS, and ESI}

Cells were cryofixed in a Leica EMPACT high pressure freezer, freeze substituted in a Leica EM AFS (Leica Microsysteme GmbH, Vienna, Austria) freeze substitution apparatus as previously described (Meindl et al. 1992; LützMeindl and Aichinger 2004) and embedded in LR-White
(London Resin Company Ltd, Theale, England). Samples were sectioned for conventional imaging and immunogold labeling in TEM into 80-nm thick sections and for EELS and electron spectroscopic imaging (ESI) to measure calcium binding capacities of mucilage and cell-wall components into $40-$ to $50-\mathrm{nm}$ thick sections. Unstained ultrathin sections mounted on hexagonal narrow mesh copper grids were incubated with $10 \mathrm{mM}$ calcium acetate (calcium-doped) for $2 \mathrm{~h}$ to over night at RT and washed briefly in one to four drops of $\mathrm{H}_{2} \mathrm{O}_{\mathrm{dd}}$ as previously described (Eder and Lütz-Meindl 2008). Calcium was measured using the calcium $\mathrm{L}_{2,3}$ edge at $344 \mathrm{eV}$. Structural analyses and element measurements were done with a LEO $912 \mathrm{AB}$ Omega transmission electron microscope (Zeiss, Oberkochen, Germany) operated at an acceleration voltage of $80 \mathrm{kV}$ for conventional imaging and immuno-TEM and at $120 \mathrm{kV}$ for EFTEM. For EELS, illumination angles between 0.8 and $4.0 \mathrm{mrad}$, magnifications between $\times 25,000$ and $\times 200,000$ and camera exposure times between 500 and $5,000 \mathrm{~ms}$ (with five to eight integration circles) were used. The measured area for EELS was defined by using a $100-\mu \mathrm{m}$ spectrometer entrance aperture. Images and EEL spectra were taken by a slow-scan dual speed CCD camera TRS Sharpeye (Troendle, Moorenwies, Germany) controlled by ESI-Vision and ITEM software (SIS, Soft Imaging Systems, Münster, Germany). Elemental maps for ESI were calculated using the three windows power law method as described by Lütz-Meindl and Lütz (2006).

\section{Results}

Development of $N$. digitus

Development of the unicellular green alga $N$. digitus was studied by digital time-lapse photography as basis for further investigations. Generally, the results confirm earlier observations in Netrium interrutpus and $N$. digitus (Jarman and Pickett-Heaps 1990; Pickett-Heaps 1975) by using more advanced techniques like the nucleus stain Syto 16 for localizing the migrating nucleus (Fig. 1a-h) and digital time-lapse video imaging (Fig. 1i-p; for details, see "Material and Methods"). $N$. digitus cells elongated from their interphase length of 120 up to $300 \mu \mathrm{m}$ before cell division by growth of their central zone. Cell division started with mitosis and formation of a septum, which finally separated the cell into two daughter cells (arrow, Fig.1a, i). Simultaneously, the chloroplast divided and formed a furrow in the middle of each future daughter cell (asterisks, Fig. 1a-c, i-k). As shown by Syto 16 staining, the two nuclei started to migrate after completion of mitosis (Fig. 1b, c, j, k). They moved first to the cell periphery (Fig. 1b-e) followed by a migration to the new centers of 

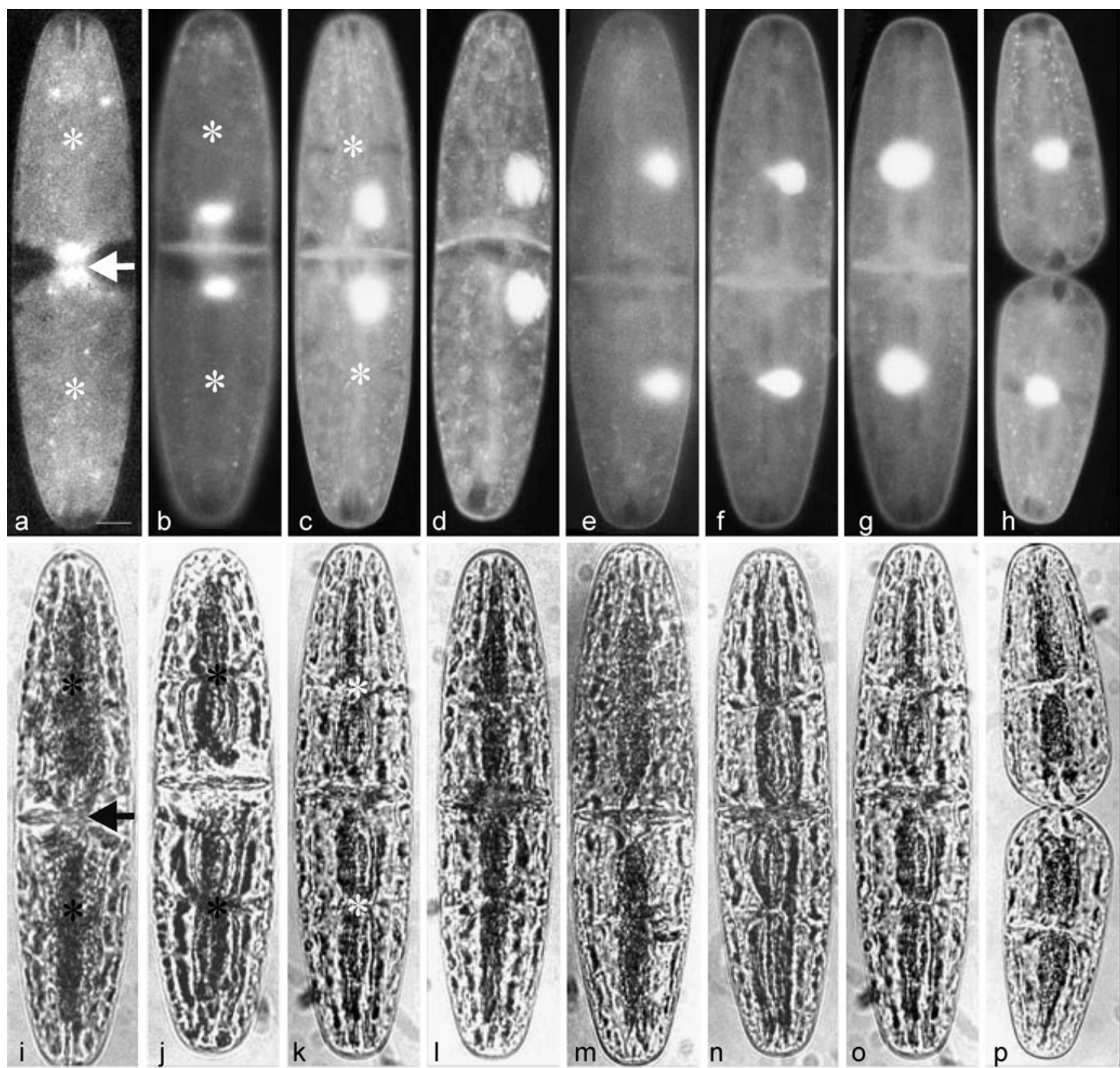

Fig. 1 Development of Netrium digitus. Fluorescence microscopic images of nuclei stained with Syto $16(\mathbf{a}-\mathbf{h})$ and corresponding brightfield micrographs (i-p). a, i Nucleus during mitosis (arrows) with

dividing chloroplasts (asterisks). $\mathbf{b}-\mathbf{g}$ Migration of nuclei. $\mathbf{h}, \mathbf{p}$ Tip growth of young semicell. Bar $20 \mu \mathrm{m}$

the daughter cells (Fig. 1f-h). After the nuclei reached their central positions, the daughter cells separated by pushing their poles away from each other (Fig. 1h, p). This process was followed by growth of the young tips until a symmetrical cell shape was reached.

\section{Mucilage excretion}

Two modes of mucilage excretion were observed in Netrium (Fig. 2a, b). Mucilage was secreted either specifically from one tip of the cell resulting in an oriented gliding motion through the substratum (Fig. 2a) or all over the surface, wrapping the cell into a thick slime layer (Fig. 2b). The latter phenomenon occurs for example in older liquid cultures (at least 4 weeks old), where Netrium cells accumulated in clusters held together by mucilage.

Cells initiated mucilage secretion through the poles when they were freshly subcultured on agar plates or when light intensity increased under the microscope, both representing stress situations. Polar mucilage secretion resulted in a gliding movement of the cell with a velocity up to $1 \mu \mathrm{m} / \mathrm{min}$. Polar mucilage secretion could switch 


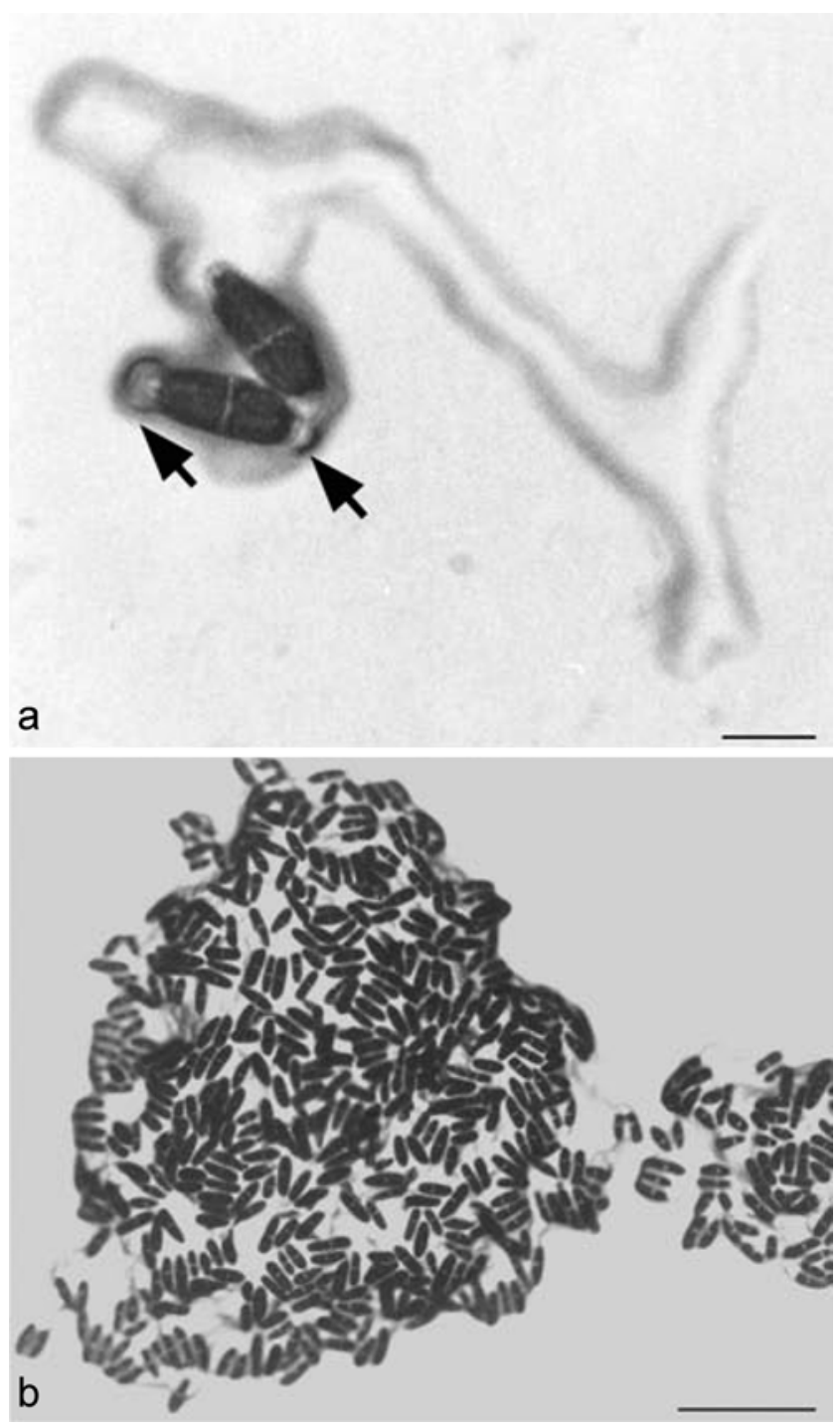

Fig. 2 Mucilage excretion of Netrium digitus cultivated on agar plates. a Mucilage tracks of two Netrium cells, with alternative sites of mucilage secretion (arrows). Bar $100 \mu \mathrm{m}$. b Clusters of Netrium cells formed by mucilage, bar $1 \mathrm{~mm}$

from one to the opposite pole (arrows, Fig. 2a). Netrium cells changed to mucilage secretion all over their surface during division and development. They continued their movement after completion of cell differentiation, leaving a mucilage track behind them at the substratum (Fig. 2a).

When viewed in SEM, Netrium cells were surrounded by a thick mucilage layer, which did not allow visualization of details of their cell surface (not shown). After removing the mucilage envelope by Bisolvon or by $0.1 \mathrm{~N} \mathrm{HCl}$ and ultrasonication, cell-wall structure became visible (Fig. 3a, b). The cell wall contained small ridges, which were aligned parallel to the longitudinal axis of the cell (Fig. 3a-c). The presence of these ridges could also be visualized by labeling the cell walls with JIM5 (e.g., Fig. $4 \mathrm{a}, \mathrm{c})$. Furthermore, small gaps in the cell wall with an average diameter of $30 \mathrm{~nm}( \pm 5 \mathrm{~nm})$ were found to be equally distributed over the whole cell surface (Fig. 3e, f). The cell tips had one slight impression at each center, which was surrounded by a caplike structure (asterisk, Fig. 3c) with randomly orientated ridges. However, no larger pores, which may be responsible for local mucilage excretion as in desmids, could be discovered. Harsher treatment of cells with $0.1 \mathrm{~N} \mathrm{HCl}$ for 30 to 40 min removed the cell wall partially and allowed visualization of inner wall layers (Fig. 3d). The covering cell-wall layer had the appearance of more loosely organized material, which was penetrated by small gaps, whereas the more compact layer located underneath contained randomly orientated cellulose fibrils but no pores (Fig. 3d).

Monosaccharide analysis of Netrium cell wall and excreted mucilage

Mucilage isolated from cells and Netrium cell walls (extracted as commonly performed in higher plants) were both analyzed for their relative monosaccharide composition (Table 1). The same monosaccharides could be detected in extracted cell wall and in mucilage of Netrium but in varying proportions. In comparison, mucilage contained significantly more fucose, xylose, and mannose than the cell wall. Surprisingly, the relative ratio of acidic monosaccharides was comparatively low in mucilage. This may be due to the occurrence of further unknown acidic monosaccharides, which have not yet been determined. Netrium cell wall contained a relatively high amount of glucose, though extracted cell wall was treated with DMSO for starch removal. The TFA insoluble fraction, expected to contain mostly cellulose, consisted of glucose as dominant monosaccharide (Table 1).

Recognition of cell wall and mucilage epitopes by antibodies

Netrium cells were labeled with JIM5, JIM7, and 2F4, which recognize pectic epitopes and with a polyclonal antibody against mucilage of Netrium to study the spatial distribution of different pectic conformations and mucilage in CLSM and to assign pectic epitopes to the corresponding ultrastructure in TEM. An overview on the results of immunolabeling both at CLSM and TEM level is given in Table 2.

JIM5 recognizes low methyl-esterified homogalacturonans, which are associated to networks by means of calcium bridges (Knox et al. 1990; Willats et al. 2000). It labels both the growing zone in the center of the cell and the growing tip of Netrium in CLSM (Fig. 4a). In developmental stages, the growing zones located close to the cell center showed marked labeling (Fig. 4b, c), 

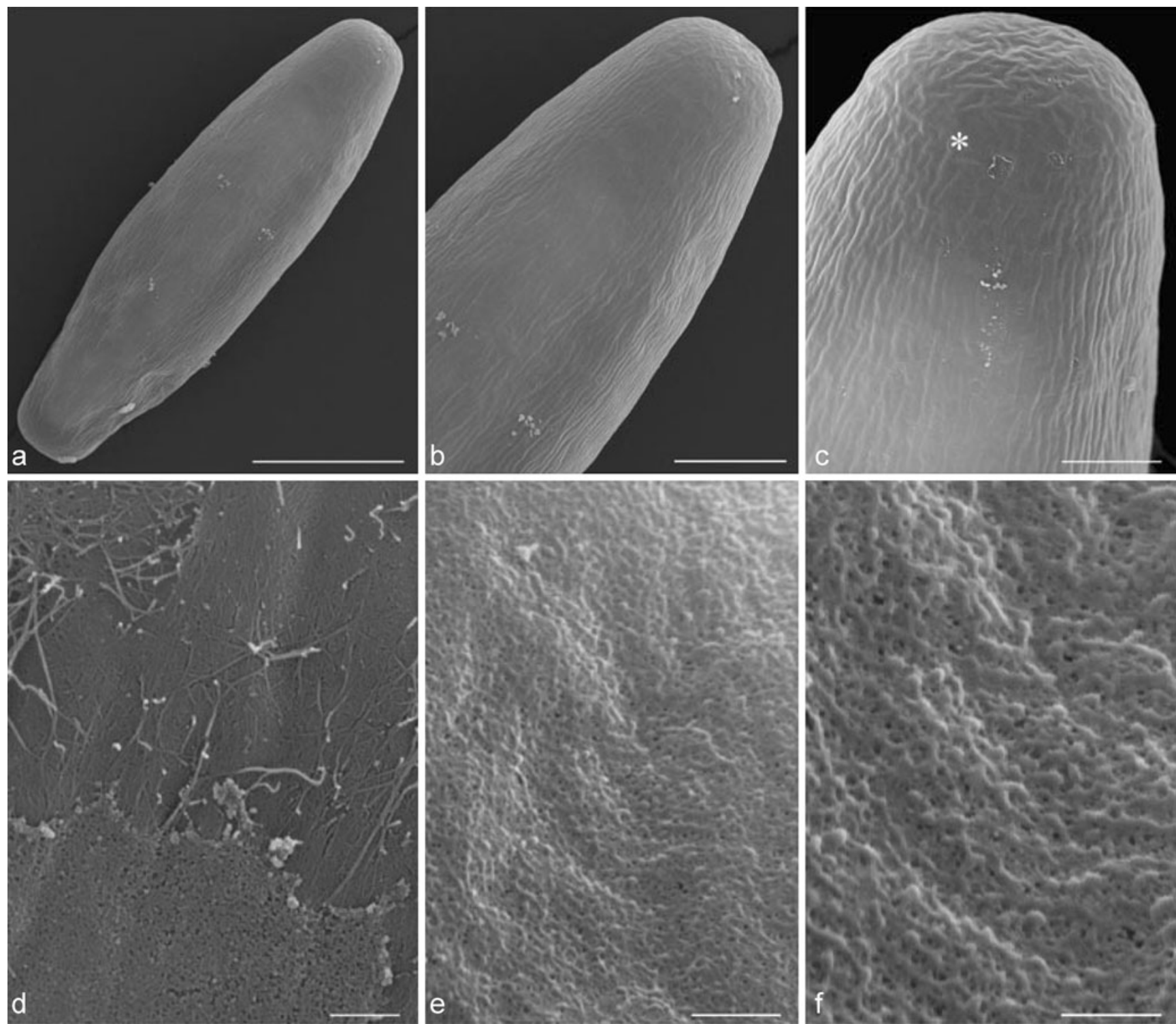

Fig. 3 Scanning electron micrographs of Netrium-treated with $\mathrm{HCl}$ to remove mucilage. a, b Whole cell with small batches of remaining mucilage, ridges, and cell tip. Bars a $50 \mu \mathrm{m}$ and b $20 \mu \mathrm{m}$. c Tip with

whereas the nongrowing areas around the tips revealed only weak fluorescence (Fig. 4c). Fixed cells, which were treated with $\mathrm{NaOH}$ for chemical de-esterification of pectins, revealed an enhanced labeling of the cell wall (Fig. 4d-f). JIM7, characterized by binding to highly methyl esterified and, thus, more loosely organized homogalacturonans (Knox et al. 1990; Willats et al. 2000) marked the cell wall weaker than JIM5, with a dominant staining in the middle of both growing and non-growing cells (Fig. $4 \mathrm{~g}-\mathrm{j}$ ). The labeling diminishes when cells were chemically deesterified with $\mathrm{NaOH}$ after fixation (Fig. 4k, 1). 2F4, binding to homogalacturonans, which are cross-linked by calcium (egg-box conformation), marked the cell wall only after de-esterification (Fig. 4m-r). Like JIM5 labeling, the cap-like structure (asterisk). Bar $10 \mu \mathrm{m}$. d Surface of cell treated with $0.1 \mathrm{M} \mathrm{HCl}$ for $40 \mathrm{~min}$. Bar $1 \mu \mathrm{m}$. e, f Outermost cell-wall layer with gap-like openings. Bars: $\mathbf{f} 1 \mu \mathrm{m}$ and $\mathbf{g} 0.5 \mathrm{~nm}$

2F4 staining varied in a developmental-dependent manner. Whereas the whole nongrowing cell was marked, particularly at the tips (Fig. 4p), the newly formed cell walls in the center of the cell were labeled during development (Fig. 4q, r). The polyclonal antibody against mucilage extensively stained the young cell wall of freshly divided cells (Fig. 4s, t, w, x). In adult stages, areas around the tips were intensively marked, whereas the middle part of the cell lacked labeling (Fig. $4 \mathrm{u}, \mathrm{v}$ ).

In dot blotting experiments, the polyclonal antibody against mucilage reacted distinctly with excreted mucilage (Fig. 5a) and with a mixture of mucilage and fixatives added to the cryo-substitution medium during preparation for TEM (Fig. 5b). Application of the pre-immune serum 

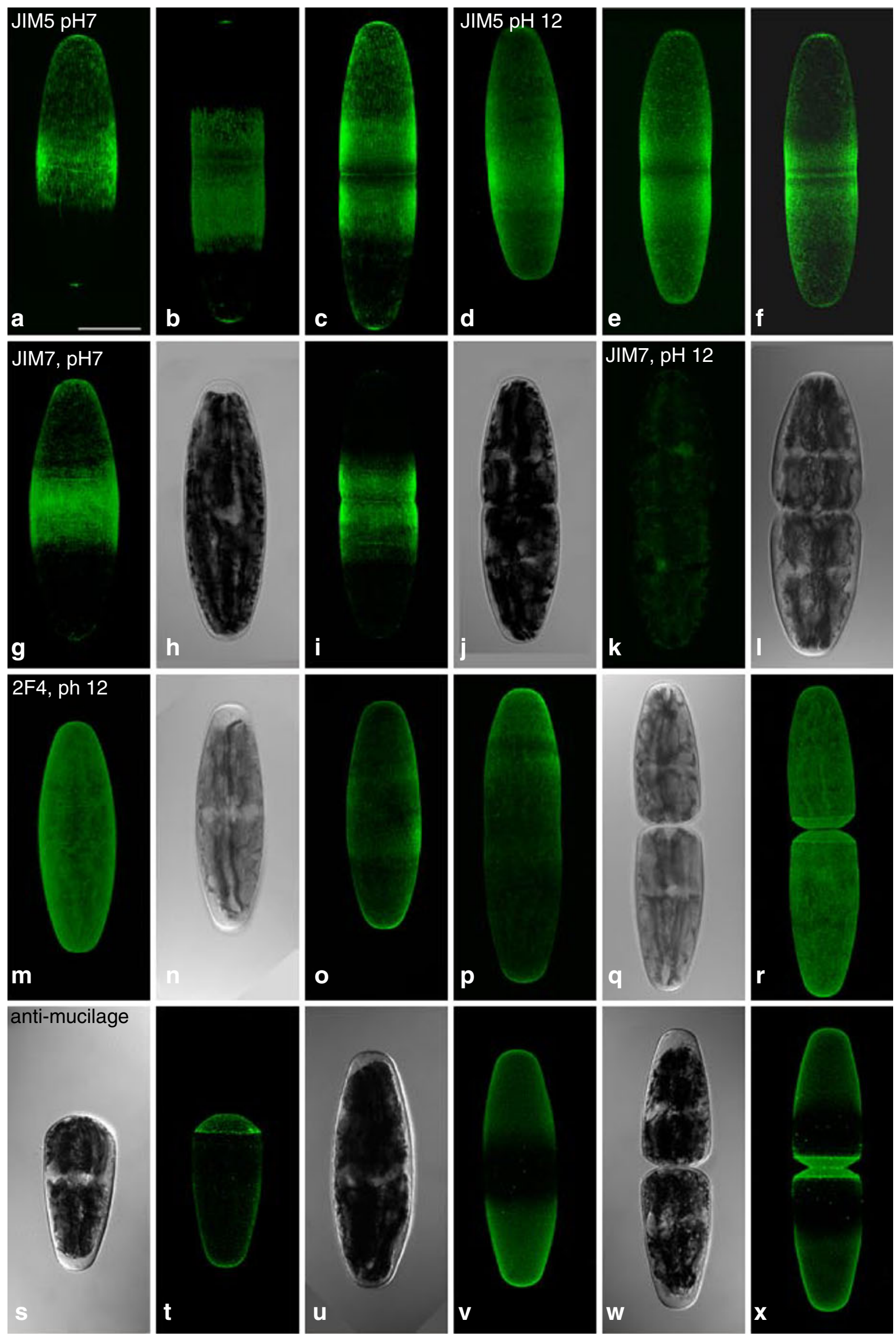
4 Fig. 4 Confocal laser scanning micrographs of Netrium labeled by JIM5 (a-f), JIM7 (g-l), 2F4 (m-r), and a polyclonal antibody against mucilage (s-x), fluorescence, and corresponding bright field images. a-c JIM5 labeling of adult (a) and of central zones in developmental stages $(\mathbf{b}, \mathbf{c})$. d-f JIM5 labeling after de-esterification with $\mathrm{NaOH} . \mathbf{g}, \mathbf{i}$ JIM7 labeling of adult (g) and developmental stage (central zones, i). $\mathbf{k}$ JIM7 labeling of developmental stage after de-esterification. $\mathbf{m}, \mathbf{o}, \mathbf{p}$, r 2F4 staining of adult stages $(\mathbf{m}, \mathbf{o})$ and developmental stages (p, r) after de-esterification with $\mathrm{NaOH}$. t, $\mathbf{v}, \mathbf{x}$ Labeling of freshly divided cells at tips $(\mathbf{t}, \mathbf{x})$ and an adult stage (v) with a polyclonal antibody against Netrium mucilage. $\mathbf{h}, \mathbf{j}, \mathbf{l}, \mathbf{n}, \mathbf{q}, \mathbf{s}, \mathbf{u}, \mathbf{w}$ corresponding bright field micrographs. Bar $50 \mu \mathrm{m}$

(Fig. 5d) and of only the secondary antibody for control (not shown) did not reveal any reaction. However, the antibody also showed a cross-reaction to extracted cell wall of Netrium (Fig. 5c).

In high-pressure frozen cryo-substituted Netrium cells, dictyosomes, important for mucilage and cell-wall material processing, were generally arranged next to lobes of the big chloroplast (Fig. 6a), which was expanded throughout the cell (Fig. 1i). All dictyosomes had a distinct cis-trans polarity; the cis-site was generally orientated towards the chloroplast, whereas the trans-site and the trans-Golgi network were directed towards the central cytoplasm or to the vacuole surrounding the chloroplast (Fig. 6a). Dictyosomes were able to produce various types of vesicle populations: small vesicles (Fig. 6a, b), voluminous vesicles supposed to contain mucilage (Fig. 6b), and vesicle stacks (Fig. 6a, i). Voluminous vesicles were produced during all developmental stages, filling a large area of the cytoplasm, whereas vesicle stacks were only synthesized in nongrowing cells. Vesicle stacks were always localized close to dictyosomes where small vesicles fused with them (Fig. 6a, i). Occasionally vesicles of these stacks were found to fuse with the big vacuole or with mucilage vesicles. Vesicle stacks were never observed in the peripheral cell areas (not shown).

Table 1 Relative monosaccharide composition of cell wall and mucilage of Netrium digitus

\begin{tabular}{lcll}
\hline Monosaccharides & cw-TFAs & cw-TFA is & Muc \\
\hline Arabinose & 5 & 0 & 7 \\
Rhamnose & 10 & 0 & 5 \\
Fucose & 17 & 0 & 30 \\
Xylose & 17 & Traces & 20 \\
Galacturonic acid & 3 & 0 & 3 \\
Glucuronic acid & 4 & Traces & 4 \\
Mannose & 2 & Traces & 6 \\
Galactose & 11 & 1 & 12 \\
Glucose & 31 & 98 & 13 \\
\hline
\end{tabular}

$c w$-TFAs cell wall-TFA-soluble fraction, $c w$-TFAis cell wall TFAinsoluble fraction, Muc Mucilage
Monoclonal antibodies raised against pectic epitopes were applied to ultrathin sections of Netrium to determine contents of vesicles involved in pectin synthesis and secretion. JIM5, recognizing low methyl esterified pectins (Knox et al. 1990), labeled mucilage vesicles (arrows, Fig. 6b), and the outer region of the cell wall, forming the frontier to the mucilage layer (Fig. 6c), but not the septum (Fig. 6d). 2F4, raised against low methyl esterified pectins in an egg-box conformation, labeled the outer side of the outer cell wall after de-esterification treatment (Fig. 6e). JIM7, recognizing highly methyl esterified pectins (Knox et al. 1990), marked two thirds of the outer cell wall, but not the mucilage layer (Fig. 6f), nor any vesicles of the secretion pathway (not shown).

The synthesis pathway of mucilage was followed by application of a polyclonal antibody against Netrium mucilage. This antibody marked voluminous vesicles (Fig. 6h) and vesicle stacks (Fig. 6i) indicating a mucilaginous nature of their content. Additionally, small vesicles pinched off from dictyosomes were labeled (Fig. 6h, i). The antibody also labeled the mucilage layer surrounding the cell, whereas the cell wall itself showed only a faint labeling in some parts (Fig. 6g).

\section{Determination of calcium binding capacities of pectins by EELS}

Ultrathin sections were treated with $10 \mathrm{mM}$ calcium acetate, rinsed, and investigated by EELS to determine cell wall and mucilage components with high calcium binding capacity (low methyl esterification degree) and, thus, with high capability to form compact and stiffened networks. Both the cell wall and the mucilage layer surrounding the wall were able to bind calcium (Fig. 7a, b). Small compact vesicles bound more calcium when compared to large mucilage vesicles (Fig. 7a, b). Measurements in the embedding medium, the cytoplasm (not shown) and in the vacuole were taken as reference (Fig. 7a, b) and did not show any calcium binding capacity. Calcium could only be measured in mucilage vesicles after they have been pinched off from dictyosomes (Fig. 7c, d).

Vesicle stacks bind only a low amount of calcium and no gradient of the calcium capacity during the maturation of the vesicles could be detected.

\section{Discussion}

Netrium, which has often been considered as an intermediate organism between simply shaped saccoderm (Mesotaeniaceae) and highly ornamented placoderm desmids (Desmidiales), was investigated for its development, ultrastructure, cell wall composition, and mucilage excretion. 
Table 2 Overview on pectin and mucilage labeling in Netrium digitus in correlation to cell growth

\begin{tabular}{lll}
\hline Antibody & Specificity & Labeling \\
\hline JIM 5 & $\begin{array}{c}\text { Middle to low methyl esterified pectins } \\
\text { (up to } 40 \% \text { esterified })^{\mathrm{a}}\end{array}$ & $\begin{array}{c}\text { CW in general, stronger staining at growth zones in cell center and tips, } \\
\text { mucilage vesicles. Enhanced labeling after de-esterification }\end{array}$ \\
JIM7 & $\begin{array}{l}\text { Middle to high methyl esterified pectins } \\
(15 \% \text { to } 80 \% \text { esterified })^{\mathrm{a}}\end{array}$ & $\begin{array}{c}\text { Growing zones of CW at cell center and tips. Labeling diminishes after } \\
\text { de-esterification }\end{array}$ \\
2F4 & De-esterified pectins & Labeling only after de-esterification at whole CW \\
Anti-mucilage & Mucilage & Newly formed tips after cell division, non-growing zones before division, \\
& & dictyosomes, secretory vesicles \\
\hline
\end{tabular}

${ }^{a}$ For references, see "Material and methods"

$\mathrm{CW}$ cell wall

Pectins known to be involved in cell-wall expansion and representing major components of mucilage have been the particular object of this study.

Investigation of cell development of Netrium by digital time lapse photography and analysis of nuclear migration by application of the nucleic acid stain Syto 16 confirmed earlier descriptions (Jarman and Pickett-Heaps 1990; Pickett-Heaps 1975). Netrium exhibits two growth phases: (1) The whole cell elongates at its center before cell division and (2) the two tips forming after septum formation grow until the cell reaches its final size. A nuclear migration occurs directly after mitosis and cell division. The mode of pre-mitotic cell elongation and the specific manner of nuclei migration is similar to primordial desmids like Penium and Closterium (Domozych et al. 2006; Jarman and Pickett-Heaps 1990; Pickett-Heaps 1975; Rogers-Domozych et al. 1993).

The cell wall of Netrium appears morphologically homogeneous, when observed in light microscope and TEM (see also Mix 1975). It contains pectic epitopes, as shown by immunolabeling with the monoclonal antibodies JIM5, JIM7, and 2F4 (for overview see Table 2). All antibodies applied resulted in a distinct and marked labeling of the developing zones, which correlates generally well with results obtained in Micrasterias and Penium (Domozych et al. 2006; Eder and Lütz-Meindl 2008; Lütz-Meindl and Brosch-Salomon 2000) as well as in higher plants (Bush and

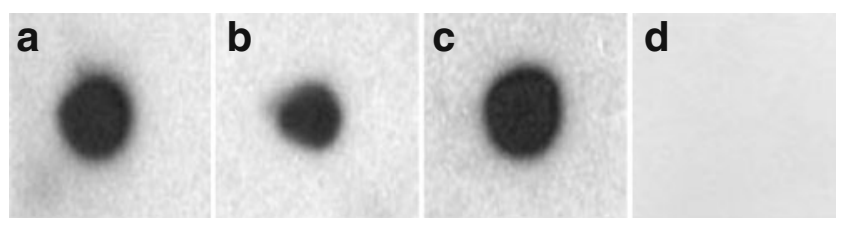

Fig. 5 Reaction of polyclonal antibody against Netrium mucilage on a dot blot against a excreted mucilage of Netrium, b excreted mucilage with fixatives in cryo-substitution medium for TEM $(1 \%$ $\mathrm{OsO}_{4}, 0.05 \%$ uranyl acetate), $\mathbf{c}$ extracted cell wall of Netrium, and $\mathbf{d}$ pre-immune serum
McCann 1999; Guillemin et al. 2005; Liners and Van Cutsem 1992). In contrast to other desmids, antibodies against pectic epitopes also label nongrowing zones of Netrium. This may be explained by a smooth transition from an expansible to a more stiffen cell wall in Netrium rather than by formation of a distinct secondary wall followed by the usual shedding of the primary wall as known from desmids (Brook 1981; Meindl 1993). The specific and antibody dependent change of the labeling pattern after chemical de-esterification with $\mathrm{NaOH}$ indicates successful de-esterification of pectic epitopes in Netrium and is in good correlation to studies in Micrasterias (Eder and Lütz-Meindl 2008) but partially in contrast to the general 2F4 labeling observed in Penium (Domozych et al. 2006). Highly methyl esterified pectins are de-esterified by $\mathrm{NaOH}$-treatment and become, thus, accessible to JIM5 and 2F4, which recognize low methyl esterified pectins. However, they become unavailable to JIM7, which recognizes high methylesterified pectins. As a consequence labeling of JIM5 and 2F4 increases after $\mathrm{NaOH}$ treatment whereas JIM7 labeling diminishes. These changes in antibody-labeling patterns after experimental de-esterification were also observed in higher plants (Guillemin et al. 2005; Knox et al. 1990; Sobry et al. 2005) as well as in Micrasterias (Eder and Lütz-Meindl 2008).

In TEM, the immuno-gold labeling of JIM5 and 2F4 at the outer side of the cell wall, which represents the border to the mucilage layer, points towards the occurrence of a pectin-calcium network responsible for wall stiffening as described earlier by Lütz-Meindl and Brosch-Salomon (2000) for Micrasterias. In higher plants, low methyl esterified pectins occur at cell corners, in middle lamellae and around air spaces, where they are thought to support resistance towards stress (e.g., Bush and McCann 1999; Liners and Van Cutsem 1992; Willats and Knox 1999; Willats et al. 2001). By forming a strong gel using calcium bridges, low methyl-esterified pectins prevent separation of cells as frequently induced by stress factors (Jarvis et al. 2003). High calcium binding capacities at the outer regions 

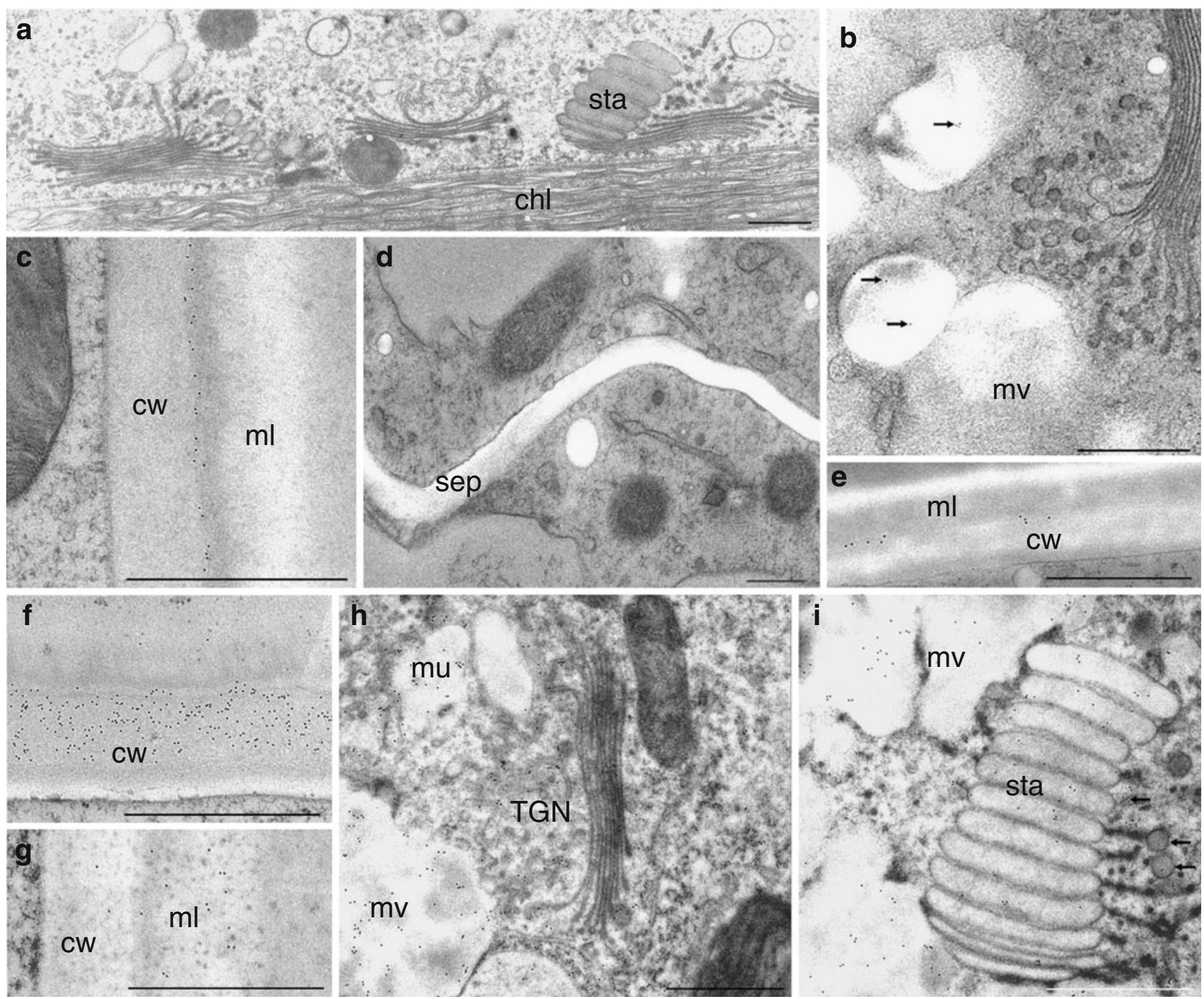

Fig. 6 Ultrastructure of Netrium digitus (a) and labeling by JIM5 (bd), 2F4 (e), JIM7 (f), and a polyclonal antibody against mucilage (g-i) in TEM. a Overview of dictyosomes arranged along the chloroplast. b Dictyosome producing small vesicles, which are fusing with mucilage vesicles marked by JIM5 (arrows). c Outer side of cell wall labeled by JIM5. d Septum not labeled by JIM5. e Outermost cell-wall layer labeled by $2 \mathrm{~F} 4$ after de-esterification. f Cell wall labeled by JIM7. $\mathbf{g}$
Marked labeling in mucilage layer and faint labeling of cell wall by polyclonal mucilage antibody. h Dictyosomal rims, mucilage vesicles, and trans-Golgi network labeled by JIM7. i Small vesicles (arrows) fusing with vesicle stacks. Vesicle stacks and mucilage vesicle labeled by polyclonal mucilage antibody. $(\mathrm{chl})$ chloroplast, $(\mathrm{cw})$ cell wall, $(\mathrm{ml})$ mucilage layer, $(\mathrm{mv})$ mucilage vesicle, (sep) septum, (sta) mucilage stacks, $(T G N)$ trans-Golgi network. Bars $1 \mu \mathrm{m}$ of the wall measured by EELS support the results from JIM5 and 2F4 antibody labeling in Netrium. The more abundant JIM7 labeling suggests that the majority of pectins found in Netrium occur in highly methyl-esterified form which correlates well with the smooth ultrastructural appearance of the cell wall and with measurements in Micrasterias (Eder and Lütz-Meindl 2008).

Biochemical monosaccharide analyses of extracted cell wall and mucilage showed the same monosaccharides but in varying concentrations, particularly concerning the glucose and rhamnose content. The higher glucose content of the cell-wall fraction may arise from polysaccharides with a hemicellulosic nature, the higher rhamnose content from pectins or hemicelluloses. A mixed-linked glucan-like polysaccharide, rich in glucose was recently found in the cell wall of Ulva lactuca L. (Popper and Fry 2003) and in Micrasterias (Eder et al. 2008). Monosaccharides of mucilage revealed a relatively high content of fucose and xylose, which is in good agreement to previous mucilage analyses of the desmids Closterium (Rogers-Domozych et al. 1993) and Cosmocladium (Surek and Sengbush 1981). The rather low content of glucuronic acid in mucilage of Netrium may have its origin in different measurement methods. Kattner et al. (1977) found three unknown 
Fig. 7 a TEM micrographs of sections pretreated with $\mathrm{Ca}$ acetate. EELS measurement sites indicated in cell wall (red), mucilage layer (dark red), compact secretory vesicle (green), and loosely organized mucilage vesicle (blue) and in the vacuole (yellow). Bar $0.5 \mu \mathrm{m}$. b Related EEL-spectra of $\mathrm{Ca}_{2}, 3$-edge. $\mathbf{c}$ TEM image with measurement sites in dictyosome (green), mucilage vesicle (red). Bar $2 \mu \mathrm{m}$. d Correlating EELspectra of $\mathrm{Ca} \mathrm{L}_{2,3}$-edge

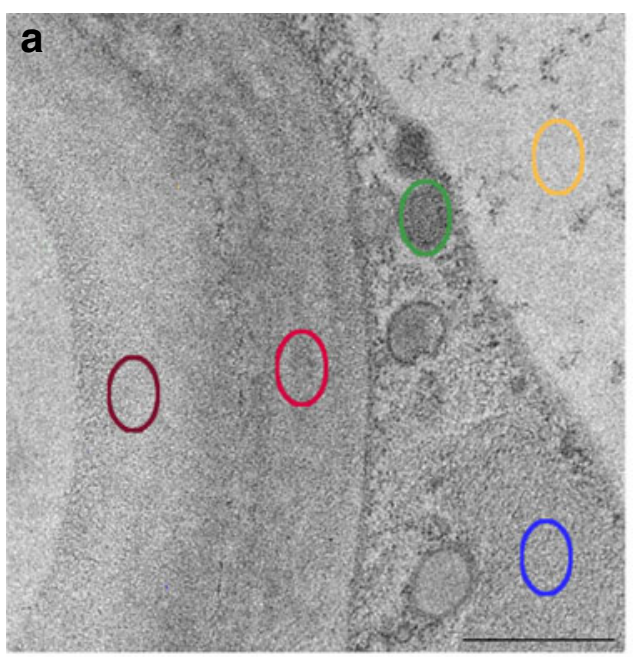

b
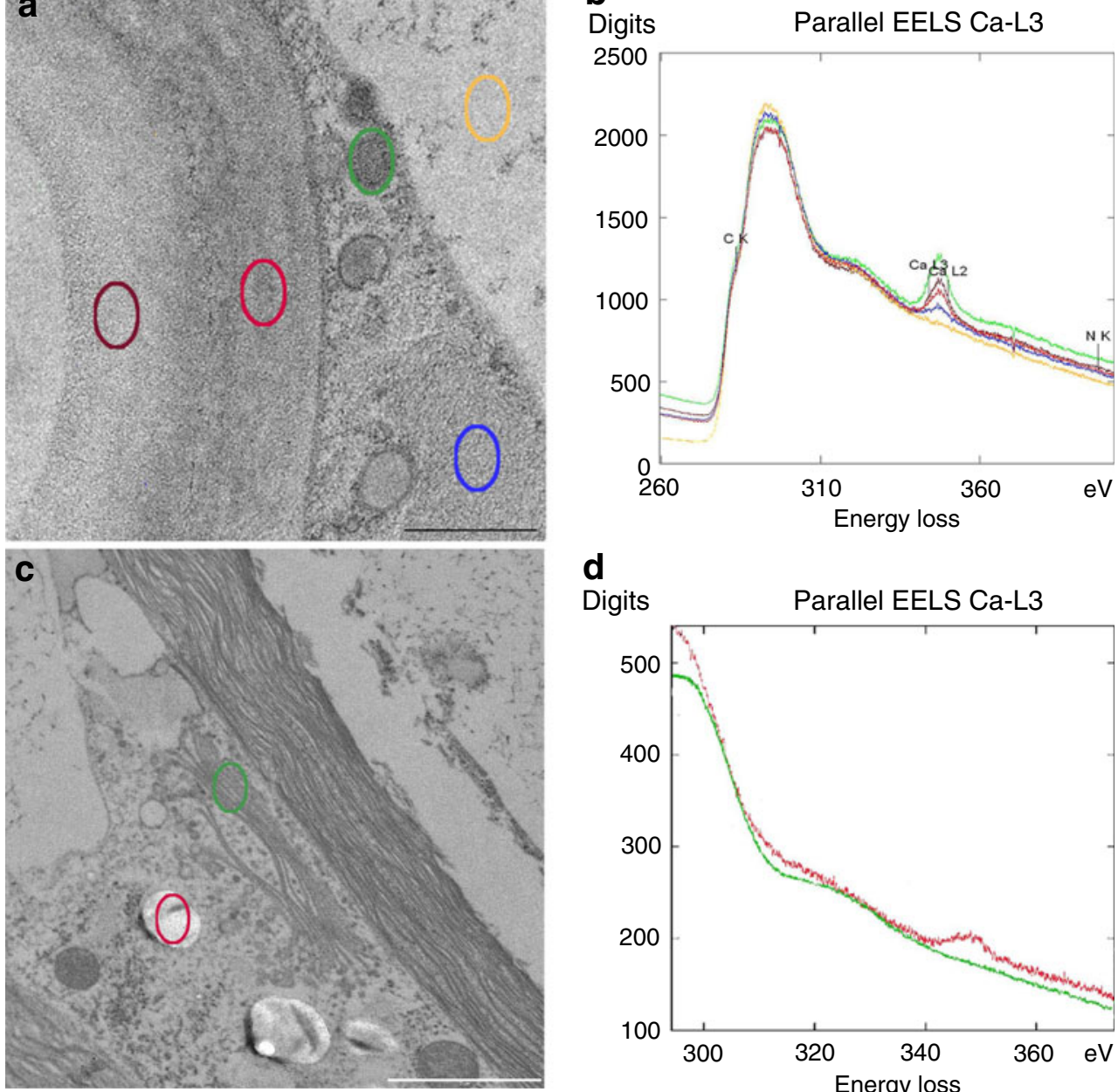

d
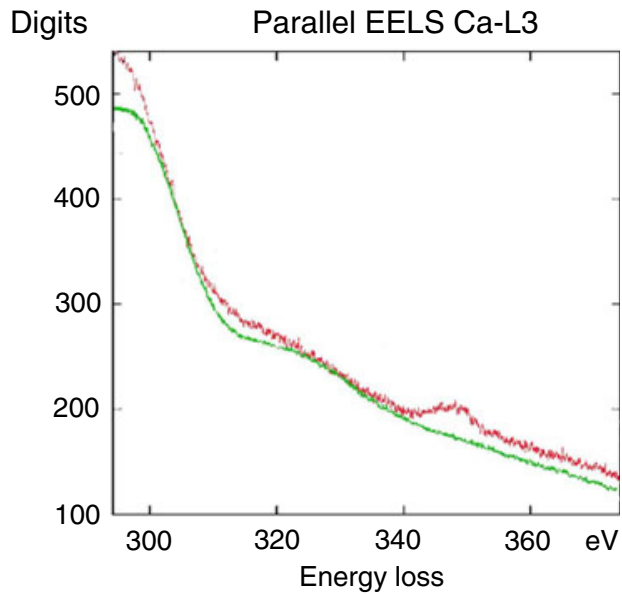

monosaccharides in excreted mucilage of Netrium by thin layer chromatography.

The polyclonal antibody against Netrium mucilage labeled not only the nongrowing areas of the cell wall, which are covered by mucilage but also the newly formed tips developing immediately after cell division in CLSM studies. This may indicate an enhanced mucilage production at this stage which obviously pushes the two daughter cells away from each other. The polyclonal antibody is specific for mucilage but labels also other secretion vesicles and both the mucilage layer and the cell wall in TEM and dot blotting experiments. This general cross reactivity is in contrast to the higher specificity of anti-mucilage antibodies raised against external Micrasterias mucilage (Oertel et al. 2004) and Closterium mucilage earlier (Domozych and Rogers-Domozych 1993) and may indicate a higher similarity between mucilage and the cell wall of Netrium than, e.g., in Micrasterias.

SEM studies reveal that the wall of Netrium lacks welldefined pores, which is in contrast to Micrasterias and other Desmidiaceae. However, we found small gaps in the outer layer of the cell wall in large numbers, which diminish at the inner layer indicating that they do not represent real pore channels penetrating the cell wall entirely. The lack of pores in the cell wall of Netrium indicates that mucilage is excreted directly through the cell wall, which, despite the presence of pores, has been also found in Micrasterias (Oertel et al. 2004). The same holds for the related algae Penium and Closterium which both reveal pore-like structures only in the outer cell-wall layer (Domozych and Rogers-Domozych 2007; Mix 1969, 1972, 1975). The similarity of Netrium with other basic desmids in its mode of cell division but its different cell wall structure strengthens the theory based on morphological (Mix 1975) and molecular data (Gontcharov et al. 2003; McCourt et al. 2000), suggesting an intermediate position of Netrium between saccoderm and placoderm desmids.

Acknowledgement We are grateful to Dr. Romana Hochreiter and Prof. Josef Thalhamer for antibody production. Prof. Azeddine 
Driouich and Dr. Eric Nguem-Ona are acknowledged for assistance in monosaccharide analyses and Dr. Wolf-Dietrich Krautgartner for his help in scanning electron microscopy. We thank Dr. Anke Oertel and Dr. Christine Lehner for introduction into some working methods and for helpful discussion. Financial support by the University of Salzburg and the Austrian Science Fund project P15849 and P 18869-B16 to U L-M is acknowledged.

Open Access This article is distributed under the terms of the Creative Commons Attribution Noncommercial License which permits any noncommercial use, distribution, and reproduction in any medium, provided the original author(s) and source are credited.

\section{References}

Baylson FA, Stevens BW, Domozych DS (2001) Composition and synthesis of the pectin and protein components of the cell wall of Closterium acerosum (Chlorophyta). J Phycol 37:796-809

Boney AD (1981) Mucilage: The ubiquitous algal attribute. Br Phycol J 16:115-132

Brook AJ (1981) The biology of desmids. Blackwell, Oxford

Brosch-Salomon S, Höftberger M, Holzinger A et al (1998) Ultrastructural localization of polysaccharides and N-acetyl-Dgalactosamine in the secretory pathway of green algae (Desmidiaceae). J Exp Bot 49:145-153

Bush MS, McCann MC (1999) Pectic epitopes are differentially distributed in the cell walls of potato (Solanum tuberosum) tubers. Physiol Plant 107:201-213

Carpita NC, Gibeaut DM (1993) Structural models of primary cell walls in flowering plants: Consistency of molecular structure with the physical properties of the walls during growth. Plant $\mathrm{J}$ $3: 1-30$

Chardard R (1977) La secretion de mucilage chez quelques desmidiales. I. Les pores. Protistologia 13:241-251

Domozych DS, Rogers-Domozych C (1993) Mucilage processing and secretion in the green alga Closterium. II. Ultrastructure and immunocytochemistry. J Phycol 29:659-667

Domozych DS, Rogers-Domozych C (2007) Desmids and biofilms in freshwater wetlands: development and microarchitecture. Microb Ecol 55:81-93

Domozych DS, Serfis A, Kiemle SN et al (2006) The structure and biochemistry of charophycean cell walls: I. Pectins of Penium margaritaceum. Protoplasma 230:99-115

Eder M, Lütz-Meindl U (2008) Pectin-like carbohydrates in the green alga Micrasterias characterized by cytochemical analysis and energy filtering TEM. J Microsc 231:201-214

Eder M, Tenhaken R, Driouich A et al (2008) Occurrence and characterization of arabinogalactan-like proteins and hemicelluloses in Micrasterias (Streptophyta). J Phycol 44:1221-1234

Giddings TH, Brower DL, Staehelin LA (1980) Visualization of particle complexes in the plasma membrane of Micrasterias denticulata associated with the formation of cellulose fibrils in primary and secondary cell walls. J Cell Biol 84:327-339

Goldberg R, Morvan C, Jauneau A et al (1996) Methyl-esterification, de-esterification and gelation of pectins in the primary cell wall. In: Visser J, Voragen AGJ (eds) Pectins and Pectinases. Elsevier Science, Amsterdam, pp 151-71

Gontcharov AA, Marin B, Melkonian M (2003) Molecular phylogeny of conjugating green algae (Zygnematophyceae, Streptophyta) inferred from SSU rDNA sequence comparisons. J Mol Evol 56:89-104

Gontcharov AA, Marin B, Melkonian M (2004) Are combined analyses better than single gene phylogenies? A case study using SSU rDNA and rbcL sequence comparisons in the Zygnematophyceae (Streptophyta). Mol Biol Evol 21:612-624
Guillemin F, Guillon F, Bonnin E et al (2005) Distribution of pectic epitopes in cell walls of the sugar beet root. Planta 222:355-371

Häder D-P (1981) Effects of inhibitors on photomovement in desmids. Arch Microbiol 129:168-172

Häder D-P (1982) Coupling of photomovement and photosynthesis in desmids. Cell Motil 2:73-82

Häder D-P, Wenderoth K (1977) Role of three basic light reactions in photomovement of desmids. Planta 137:207-214

Hanley S, Revol J-F, Godbout L et al (1997) Atomic force microscopy and transmission electron microscopy of cellulose from Micrasterias denticulata; evidence for a chiral helical microfibril twist. Cellulose 4:209-220

Holzinger A, Lütz-Meindl U (2003) Evidence for kinesin- and dyneinlike protein function in circular nuclear migration in the green alga Pleurenterium tumidum: Digital time lapse analysis of inhibitor effects. J Phycol 39:106-114

Jarman M, Pickett-Heaps J (1990) Cell division and nuclear movement in the saccoderm desmid Netrium interruptus. Protoplasma 157:136-143

Jarvis MC, Briggs SPH, Knox JP (2003) Intercellular adhesion and cell separation in plants. Plant Cell Environ. 26:977-979

Kattner E, Lorch D, Weber A (1977) Die Bausteine der Zellwand und der Gallerte eines Stammes von Netrium digitus (Ehrbg.) ITZIGS and ROTHE. Mitt Inst Allg Bot Hamburg 15:33-39

Kearns KD, Hunter MD (2000) Green algal extracellular products regulate antialgal toxin production in a cyanobacterium. Environ Micobiol 2:291-297

Kiermayer O (1964) Untersuchungen über die Morphogenese und Zellwandbildung bei Micrasterias denticulata Bréb. Allgemeiner Überblick. Protoplasma 59:328-420

Kiermayer O, Sleytr UB (1979) Hexagonally ordered "rosettes" of particles in the plasma membrane of Micrasterias denticulata Brèb. and their significance for microfibril formation and orientation. Protoplasma 101:133-139

Kim N-H, Herth W, Vuong R, Chanzy H (1991) The cellulose system in the cell wall of Micrasterias. J Struct Biol 117:195-203

Knox JP, Linstead PJ, King J et al (1990) Pectin esterification is spatially regulated both within cell walls and between developing issues of root apices. Planta 181:512-521

Lind JL, Heimann K, Miller EA et al (1997) Substratum adhesion and gliding in a diatom are mediated by extracellular proteoglycans. Planta 203:213-221

Liners F, Letesson J-J, Didembourg C et al (1989) Monoclonal antibodies against pectin. Recognition of a conformation induced by calcium. Plant Physiol 91:1419-1424

Liners F, Van Cutsem P (1992) Distribution of pectic polysaccharides throughout walls of suspension-cultured carrot cells. Protoplasma $170: 10-21$

Lütz C, Seidlitz HK, Meindl U (1997) Physiological and structural changes in the chloroplast of the green alga Micrasterias denticulata induced by UV-B simulation. Plant Ecol 128:54-64

Lütz-Meindl U, Aichinger N (2004) Use of energy filtering transmission electron microscopy for routine ultrastructural analysis of high-pressure frozen or chemically fixed plant cells. Protoplasma 223:155-162

Lütz-Meindl U, Brosch-Salomon S (2000) Cell wall secretion in the green alga Micrasterias. J Microsc 198:208-217

Lütz-Meindl U, Lütz C (2006) Analysis of element accumulation in cell wall attached and intracellular particles of snow algae by EELS and ESI. Micron 37:452-458

McCourt R, Karol KG, Bell J et al (2000) Phylogeny of the conjugating green algae (Zygnematophyceae) based on rbc L sequences. J Phycol 36:747-758

Meindl U (1993) Micrasterias cells as a model system for research on morphogenesis. Microbiol Rev 57:415-433 
Meindl U, Lancelle S, Hepler PK (1992) Vesicle production and fusion during lobe formation in Micrasterias visualized by highpressure freeze fixation. Protoplasma 170:104-114

Menge U (1976) Ultracytochemische Untersuchungen an Micrasterias denticulata Bréb. Protoplasma 88:287-303

Mix M (1969) Zur Feinstruktur der Zellwände in der Gattung Closterium (Desmidiaceae) unter besonderer Berücksichtigung des Porensystems. Arch Mikrobiol 68:306-325

Mix M (1972) Die Feinstruktur der Zellwände bei Mesontaeniaceae und Gonatophyceae mit einer vergleichenden Betrachtung der verschiedenen Wandtypen der Conjugatophyceae und über deren systematischen Wert. Arch Mikrobiol 81:197-220

Mix M (1975) Die Feinstruktur der Conjugaten und ihre systematische Bedeutung. Beih Nova Hedvegia 42:179-194

Nakashima J, Heathman A, Brown M (2006) Antibodies against a Gossypium hirsutum recombinant cellulose synthase (Ces A) specifically label cellulose synthase in Micrasterias denticulata. Cellulose 13:181-190

Neuscheler W (1967) Bewegung und Orientierung bei Micrasterias denticulata (Bréb) im Licht. Zeitschr Pflphysiol 57:46-59

Oertel A, Aichinger N, Hochreiter R et al (2004) Analysis of mucilage secretion and excretion in Micrasterias (Chlorophyta) by means of immunoelectron microscopy and digital time lapse video microscopy. J Phycol 40:711-720

Pickett-Heaps J (1975) Green algae. Structure reproduction and evolution in selected genera. Sinauer, Sunderland

Pickett-Heaps JD, West JA, Wilson SM et al (2001) Time-lapse videomicroscopy of cell (spore) movement in red algae. Eur J Phycol 36:9-22

Popper ZA, Fry SC (2003) Primary cell wall composition of bryophytes and charophytes. Ann Bot 91:1-12

Ray B, Lahaye M (1995) Cell-wall polysaccharides from the marine green alga Ulva "rigida" (Ulvales, Chlorophyta). Chemical structure of ulvan. Carbohydr Res 274:313-318

Ray B, Loutelier-Bourhis C, Lange C et al (2004) Structural investigation of hemicellulosic polysaccharides from Argania spinosa: characterization of a novel xyloglucan motif. Carbohydr Res 339:201-208

Rogers-Domozych C, Plante K, Blais P et al (1993) Mucilage processing and secretion in the green alga Closterium. I. Cytology and biochemistry. J Phycol 29:650-659

Schlösser UG (1982) Sammlung von Algenkulturen. Ber Deutsch Bot Ges 95:181-276

Sobry S, Havelange A, Van Cutsem P (2005) Immunocytochemistry of pectins in shoot apical meristems: consequences for intracellular adhesion. Protoplasma 225:15-22

Surek B, Sengbush PV (1981) The localization of galactosyl residues and lectin receptors in the mucilage and cell walls of Cosmocladium saxonicum (Desmidiaceae). Protoplasma 108:149-161

Trojánková K, Poibyl P (2006) Negative photomovements of desmid Micrasterias rotata as response to strong light. Czech Phycol 6:135-142

Url W and Kusel-Fetzmann EL (1973) Desmidiaceae. Fortbewegung durch Schleimausscheidung. Publ. Scientific Film E1913

Vammen K (1977) Studium des Wachstums von Micrasterias denticulata in Reinkultur. Thesis, Salzburg

Vitkov L, Krautgartner WD, Hanning M et al (2001) Fimbriamediated bacterial adhesion to human oral epithelium. FEMS Microbiol Lett 202:25-30

West W, West GS (1904) A monograph of British Desmidiaceae. Ray Society, London

Willats WGT, Knox JP (1999) Immunoprofiling of pectic polysaccharides. Anal Biochem 268:143-146

Willats WGT, Limberg G, Buchholt HC et al (2000) Analysis of pectic epitopes recognised by hybridoma and phage display monoclonal antibodies and enzymatic degradation. Carbohydr Res 327:309-320

Willats WGT, Orfila C, Limberg G et al (2001) Modulation of the degree and pattern of methyl-esterification of pectic homogalacturonan in plant cell walls. J Biol Chem 276:1940419413

Yamagishi T (1963) Classification of the Zygnemataceae. Sci Rep Tokyo Kyoiku Daigaku B 11:191-210 